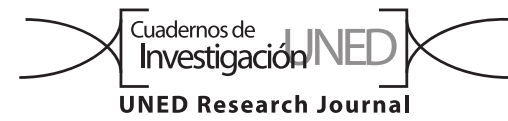

\title{
Climate change and tropical marine ecosystems: A review with an emphasis on coral reefs
}

\author{
Joan A. Kleypas \\ National Center for Atmospheric Research, Boulder, CO 80307-3000 USA; kleypas@ucar.edu \\ Received 28-VII-2018 • Corrected 19-X-2018 • Accepted 14-I-2019
}

\begin{abstract}
Climate change is usually associated with warming and weather extremes that impact the human environment and terrestrial systems, but it also has profound effects on the ocean, which is probably the most unique, life-supporting feature of planet Earth. The most direct consequence of rising $\mathrm{CO}_{2}$ concentration in the atmosphere is "ocean acidification," a term that refers to the lowering of seawater $\mathrm{pH}$, but encompasses a suite of chemical changes that affect marine organisms from shell formation, to reproduction, physiology, and behavior. The oceans are also warming in pace with the atmosphere, and in fact store the vast majority of the additional heat generated by rising $\mathrm{CO}_{2}$ and other greenhouse gases in the atmosphere. This warming is causing the more mobile marine species to redistribute poleward and deeper, and is causing high mortality in more sessile species such as those that build and habituate coral reefs. But warming is also leading to a decrease in dissolved oxygen in the oceans. For tropical marine ecosystems, the combination of ocean acidification, warming, and deoxygenation will continue to impact marine ecosystems in the future. The extent of these impacts depends on which energy pathway society follows, and our abilities to reduce other stressors and assist the rate at which species can adapt and migrate to more suitable environments.
\end{abstract}

Key words: oceans, climate change, ocean acidification, ocean warming, ocean deoxygenation.
RESUMEN: El cambio climático y los ecosistemas marinos tropicales: una revisión con énfasis en los arrecifes de coral. El cambio climático generalmente está asociado con el calentamiento y las condiciones climáticas extremas que impactan el ambiente humano y los sistemas terrestres, pero también tiene profundos efectos en el océano, que es probablemente la característica más importante del planeta Tierra para mantener la vida. La consecuencia más directa del aumento de la concentración de $\mathrm{CO}_{2}$ en la atmósfera es la "acidificación del océano", que se refiere a la disminución del pH del agua de mar, pero abarca un conjunto de cambios químicos que afectan a los organismos marinos desde la formación de conchas hasta la reproducción, fisiología y comportamiento. Los océanos también se están calentando como la atmósfera, y de hecho almacenan la gran mayoría del calor adicional generado por el aumento de $\mathrm{CO}_{2}$ y otros gases de efecto invernadero en la atmósfera. Este calentamiento está causando que las especies marinas más móviles se redistribuyan hacia los polos y a más profundidad, y está causando una alta mortalidad en especies más sésiles, como las que construyen y habitúan los arrecifes de coral. Pero el calentamiento también está conduciendo a una disminución del oxígeno disuelto en los océanos. Para los ecosistemas marinos tropicales, la combinación de acidificación, calentamiento y desoxigenación de los océanos continuará afectando los ecosistemas marinos en el futuro. El alcance de estos impactos depende de la ruta energética que siga la sociedad y de nuestra capacidad para reducir otros factores estresantes y ayudar a la velocidad a la que las especies pueden adaptarse y migrar a entornos más adecuados.

Palabras clave: océanos, cambio de clima, acidificación de océano, calentamiento de océano, desoxigenación.
Earth was not considered a "blue" planet until spaceflight allowed the Earth to be viewed from outer space. The most famous "Blue Marble" photographs of Earth were taken from the Apollo 17 spacecraft in 1972 (Fig. 1). Prior to this time, few persons thought of the Earth as being predominantly blue, but its distinctive color is persistent even when Earth is viewed from distances as far away as Saturn (Fig. 1).
The blue color of the planet highlights the unique nature of Earth in having an abundance of water at is surface. There is still debate about why water is abundant on Earth but rare on other planets in our solar system. The two main theories are that the water was released from the interior of the planet through processes of plate tectonics, or that it was carried in as meteorites during an early phase of Earth history. Regardless of the origin, the 


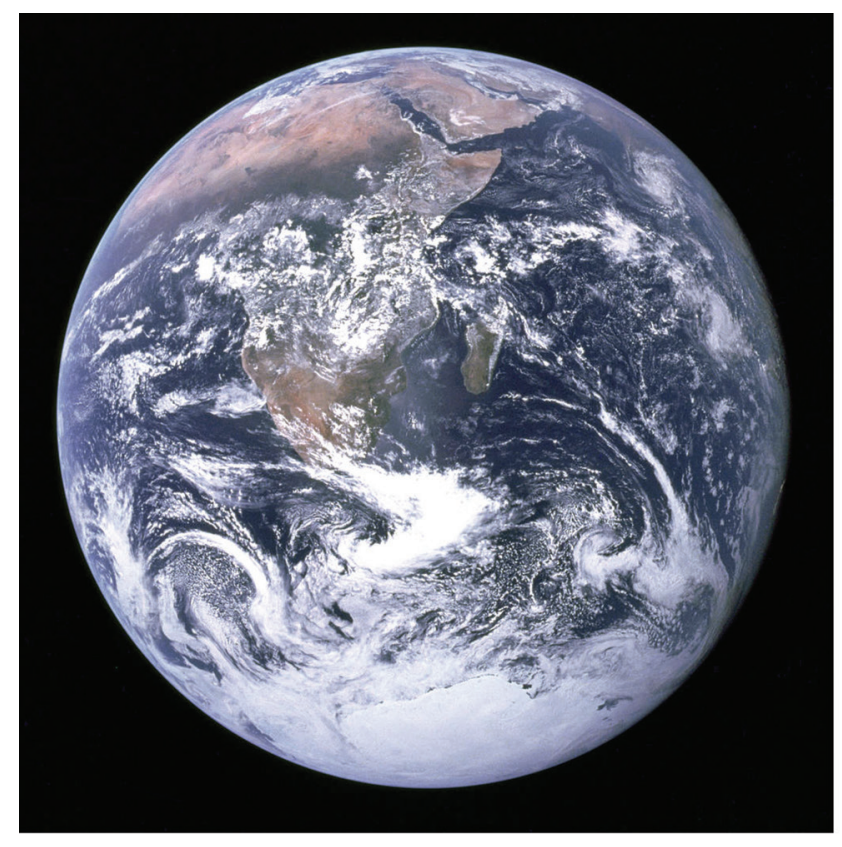

Fig. 1. A) The famous "blue marble" photograph of Earth taken by the Apollo $17 \mathrm{crew}$ in 1972. B) Image of planet Earth taken on July 19, 2013, with the wide-angle camera on NASA's Cassini spacecraft as it was photographing Saturn. The arrow points to Earth, which was 1,44 billion $\mathrm{Km}$ from Cassini. The photo was one of a series of wide-angle photos taken as part of a mosaic of photos of Saturn, and this is the only one that captured the Earth-moon system in the background. Credit for both images: NASA.

prevalence of water is what supports the abundance and diversity of life that makes up the biosphere.

Although the Earth's atmosphere and hydrosphere are such notable features of the planet, they are more finite than they appear. Technically the atmosphere is some $480 \mathrm{Km}$ thick, but $75 \%$ of its mass is contained within the troposphere, the lowermost layer of the atmosphere, with a thickness that varies between $7-18 \mathrm{Km}$. Similarly, although the ocean is considered prohibitively deep, its average depth is only $3,7 \mathrm{Km}$ and its deepest depth only

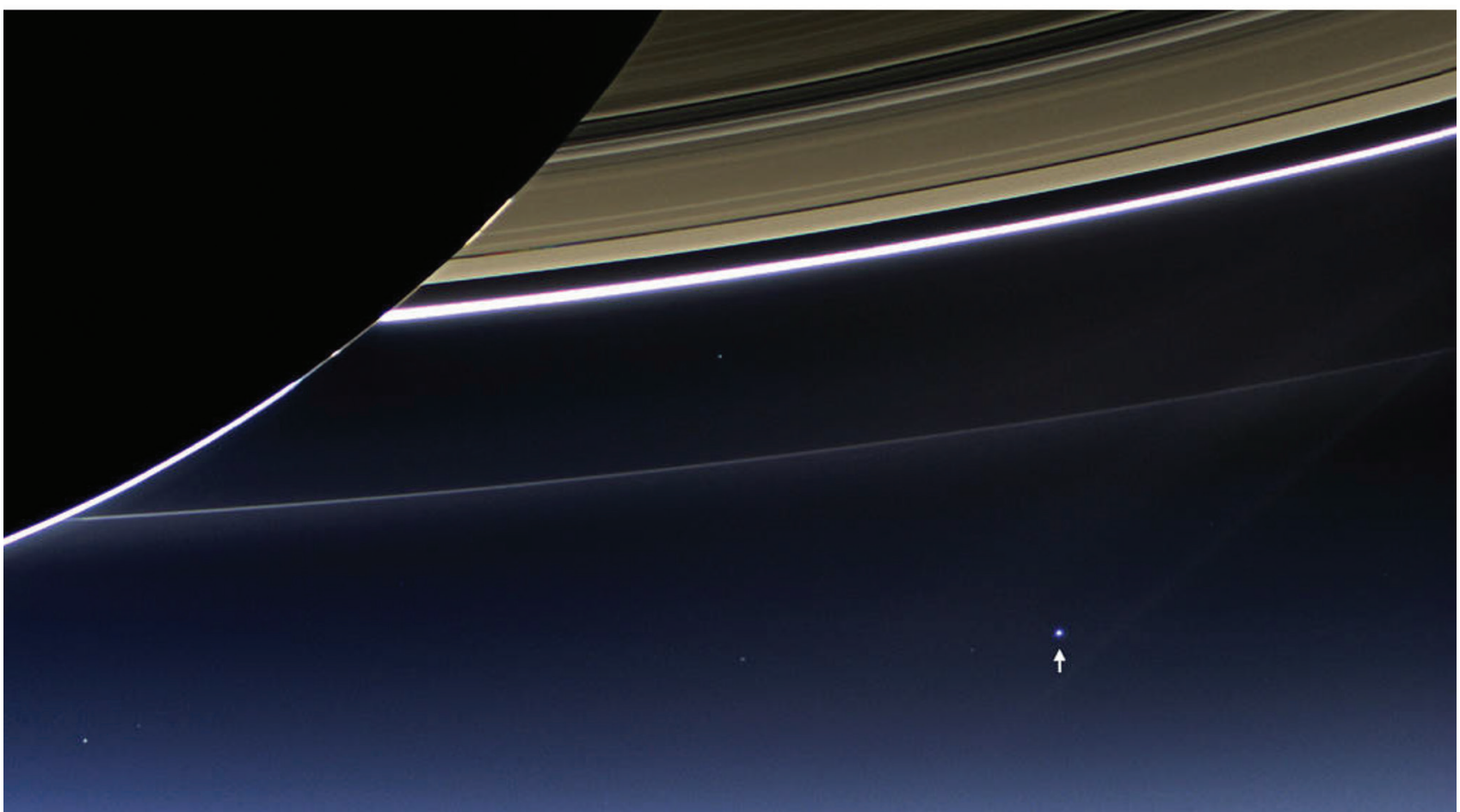

$11 \mathrm{Km}$. To put this in perspective, the thickness of the troposphere or the hydrosphere is less than the average distance one travels to work every day. Relative to Earth's radius $(6356 \mathrm{Km})$ these two spheres are almost film-like, which helps one understand why the ocean and the atmosphere can and do change over time.

The oceans render the planet habitable for many reasons and the main ones are listed here. First, the high heat capacity of water allows the oceans to store much of the solar radiative heating of the planet, and also modulates the temperature of the planet at a global scale. Not only does its high heat capacity regulate extreme changes in temperature, ocean currents also move warm waters into cooler areas and vice versa. Second, the oceans help regulate the concentration of various gases in our atmosphere. Air-sea gas exchange, for example, moves 
gases between the ocean and atmosphere reservoirs of carbon dioxide, oxygen, and nitrogen gas. The ocean is also the source of about $85 \%$ of water vapor in the atmosphere. Third, oceans provide $50 \%$ of the oxygen in the atmosphere. The vast majority of the oceanic sources of oxygen are microscopic phytoplankton that live in the upper $100 \mathrm{~m}$ of the ocean where light levels are sufficient to support photosynthesis.

Unfortunately, our knowledge of ocean life is poor relative to that of the terrestrial environment, mainly because of the technical difficulty of working in an environment that is challenging to humans and technology. An estimated 2,2 million species live in the ocean, with only about $10 \%$ actually catalogued (Mora, Tittensor, Adl, Simpson \& Worm, 2011). Even less is known about the life strategies, behavior, and ecological aspects of most of them, yet what we do know illustrates that ocean life has as many complexities as does life on land. And just as terrestrial life and ecosystems will be affected by climate change, so will ocean life, and perhaps even more so. That forms the basis of this review: to provide a brief summary of the most important challenges of climate change to tropical marine ecosystems: ocean acidification, ocean warming, and ocean deoxygenation.

\section{CLIMATE CHANGE = OCEAN CHANGE}

Carbon dioxide is an essential gas in our atmosphere because it helps maintain surface temperatures within the range where all three phases of water (frozen, liquid, and gas) can exist, but mostly between the $0-100^{\circ} \mathrm{C}$ range (liquid phase) that is essential to nearly all forms of life. Burning of fossil carbon (coal, oil, and gas) as well as modern carbon (forests, grasslands, and garbage) releases carbon dioxide that builds up in the atmosphere. That buildup causes two major changes in the ocean: acidification and warming, and the latter leads to a third problem of decreasing oxygen concentration.

Ocean Acidification: The oceans absorb about 23\% of carbon dioxide emissions every year (Le Quéré et al., 2018). When integrated over time, the oceans have absorbed nearly half of the carbon dioxide that has been added to the atmosphere since the beginning of the industrial revolution (Sabine et al., 2004; Khatiwala et al., 2013). Seawater naturally contains a large amount of dissolved carbon that is partitioned between four chemical compounds: dissolved carbon dioxide $\left(\mathrm{CO}_{2}\right)$, carbonic acid $\left(\mathrm{H}_{2} \mathrm{CO}_{3}\right)$, bicarbonate ions $\left(\mathrm{HCO}_{3}{ }^{-}\right)$and carbonate ions $\left(\mathrm{CO}_{3}{ }^{2-}\right)$. The uptake of additional $\mathrm{CO}_{2}$ by seawater raises the total concentration of dissolved carbon, that is the sum of these compounds. The relative concentrations of the compounds shift to maintain charge balance (Fig. 2), which is collectively referred to as the "carbonate buffer system" that helps to maintain $\mathrm{pH}$. Even so, the addition of $\mathrm{CO}_{2}$ to seawater results in a measurable decrease in $\mathrm{pH}$ (i.e., an increase in the hydrogen ion concentration), which is why the process is called "ocean acidification."

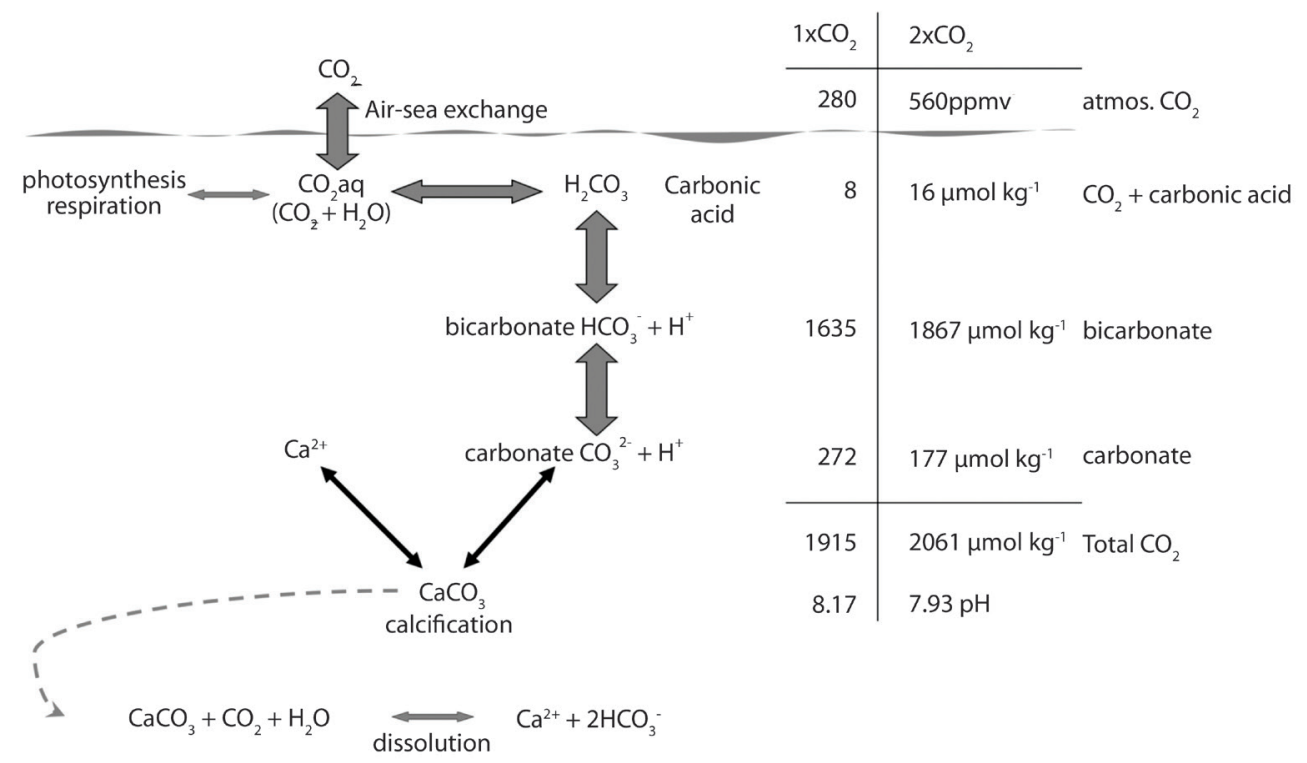

Fig. 2. How rising atmospheric $\mathrm{CO}_{2}$ in the atmosphere affects the balance of the carbonate system in seawater. The scale at the right shows the changes in the concentrations of the various parameters between the preindustrial concentration of $\mathrm{CO}_{2}$ in the atmosphere $\left(1 \times \mathrm{CO}_{2}, 280 \mathrm{ppmv}\right)$, and a doubling of that concentration $\left(2 \times \mathrm{CO}_{2}, 560 \mathrm{ppmv}\right)$, a level projected for the middle of the $21^{\text {st }}$ century. The equation at the bottom represents how the addition of $\mathrm{CO}_{2}$ to water leads to the dissolution of calcium carbonate $\left(\mathrm{CaCO}_{3}\right)$. 
Ocean acidification is a problem for many organisms that secrete calcium carbonate $\left(\mathrm{CaCO}_{3}\right)$, particularly organisms that secrete the more soluble $\mathrm{CaCO}_{3}$ mineral forms of aragonite (e.g., corals) and high-magnesium calcite (e.g., coralline algae and echinoderms). For tropical coral reefs, ocean acidification is known to affect the ability of these organisms to secrete their shells, but it also causes the reef framework and sediments to dissolve more rapidly. This leads to a loss of reef structural complexity (Alvarez-Filip, Gill \& Dulvy, 2011), which supports reef biodiversity, and a loss in reef integrity, which serves to protect shorelines from erosion. Evidence of the impacts of acidification on coral reef ecosystems is found where reefs and other carbonate producing communities occur near natural $\mathrm{CO}_{2}$ seeps in the ocean (Hall-Spencer et al., 2008; Fabricius et al., 2011; Inoue, Kayanne, Yamamoto \& Kurihara, 2013). The sites are characterized by a gradient of low $\mathrm{pH}$ conditions near the seeps, which mimic future ocean $\mathrm{pH}$ conditions, to natural $\mathrm{pH}$ conditions away from the seeps. Multiple studies have documented the expected shifts in the reef ecosystems at lower $\mathrm{pH}$ : an increase in seagrass production but decreases in carbonate production, reef structural complexity, biological diversity, and coral recruitment (Fig. 3) (Fabricius, Noonan, Abrego, Harrington \& De'ath, 2017). The causes for the decrease in coral recruitment point to laboratory studies that show a reduction in the compounds produced by coralline algae that attract coral larvae to settle (Webster, Uthicke, Botte, Flores \& Negri,
2013), and studies that show that newly settled coral larvae produce thinner skeletons that become easily broken (Doropoulos, Ward, Marshell, Diaz-Pulido \& Mumby, 2012).

Many studies document additional effects of ocean acidification on marine life and biodiversity (summarized in Kleypas, 2019). These cannot be adequately described here, but ocean acidification has been shown to affect primary production and food web dynamics, the nutritional value of that production to herbivores, the production of toxins by marine algal blooms, animal behavior, and almost every stage of reproduction. It should be noted that most of these impacts are not universal across all organisms; rather, the rule is that these impacts range widely between species and even within species. The composite result of multiple species being affected differently, however, is likely to lead to shifts in species competition, predator-prey interactions, and ultimately biodiversity.

Ocean warming: Even though the oceans absorb much of the carbon dioxide released to the atmosphere by fossil fuel burning, about $50 \%$ remains in the atmosphere each year and accumulates over time. The global concentration of atmospheric $\mathrm{CO}_{2}$ today (2018) is about 409 ppmv, which is nearly $50 \%$ higher than it was prior to 1880 , i.e. before industrialization. Carbon dioxide gas is transparent to incoming long-wave radiation of the sun, but it absorbs the infrared radiation emitted back
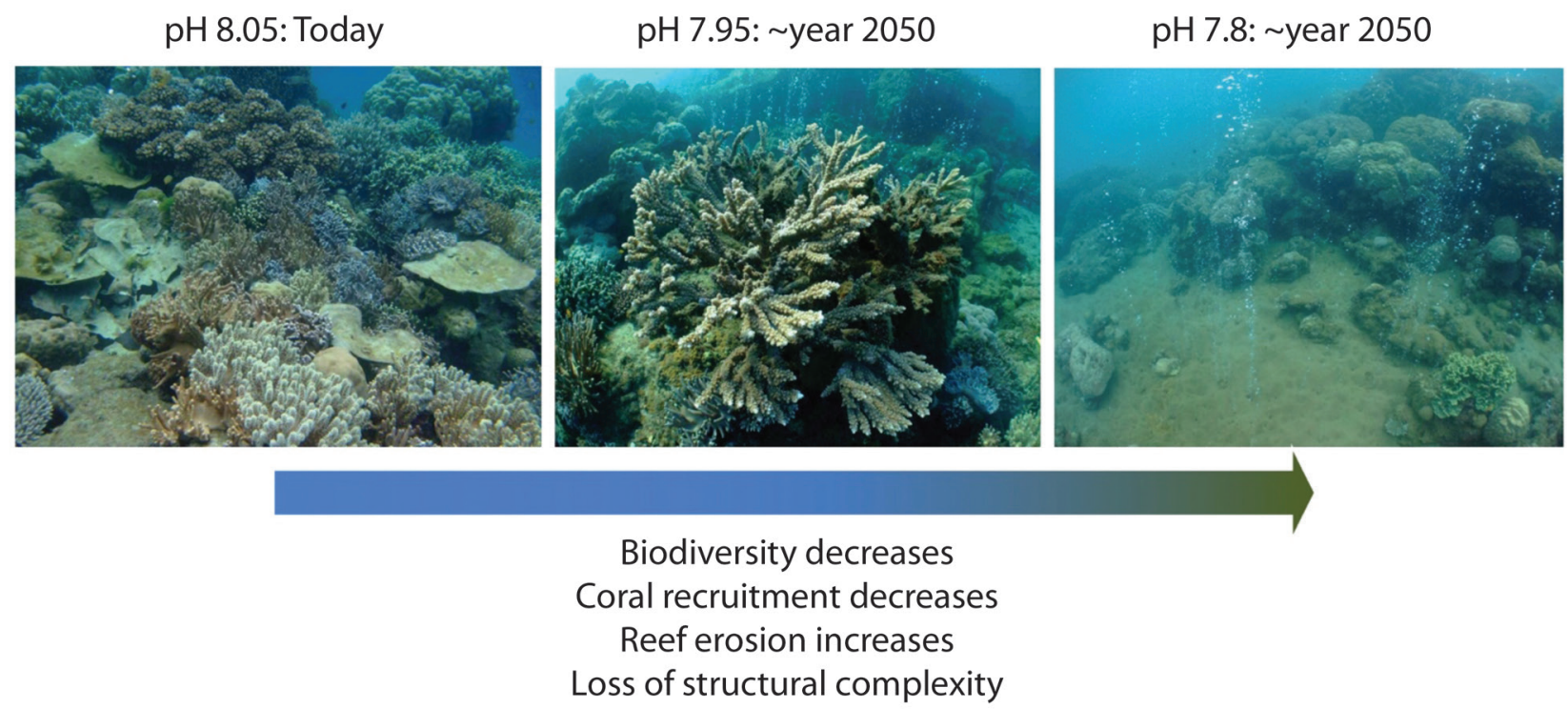

Fig. 3. Photographs of a coral reef ecosystem near a submarine $\mathrm{CO}_{2}$ vent system, showing changes in the coral community structure and reef structure located (a) in normal $\mathrm{pH}$ conditions, (b) in $\mathrm{pH}$ conditions similar to those projected for the middle of the $21^{\text {st }}$ century, and (c) in $\mathrm{pH}$ conditions similar to those projected for the end of the $21^{\text {st }}$ century. Photographs provided by Dr. Katharina Fabricius (Australian Institute of Marine Science), in association with the publication of Fabricius et al. (2011). 
toward space by the Earth. This is the main cause of global warming. As stated earlier, however, more than $90 \%$ of the heat generated by this process is transferred to the ocean. This does not mean that ocean temperature is rising faster than temperature of the atmosphere, but it reflects two main facts: (1) the specific heat of water is about four times that of air, i.e., it requires much more heat to change the temperature of a mass of water than it does an equal mass of air; and (2) while the surface ocean absorbs heat from the atmosphere, ocean circulation slowly transports some of the heat to deeper regions. For the past 40 years, the global average surface temperature of the Earth, including land and ocean, has consistently been greater than the $20^{\text {th }}$ century global average. Averaged over the past 5 years (2013-2017) average surface temperature is now $0,82^{\circ} \mathrm{C}$ warmer than the $20^{\text {th }}$ century average, with 2016 being the record high-temperature year at $0,94^{\circ} \mathrm{C}$ warmer. The average temperature of the global ocean surface has warmed more slowly; the average temperature in 2017 was about $0,67^{\circ} \mathrm{C}$ above that for the $20^{\text {th }}$ century (NOAA, 2018). For tropical coral reef waters, temperatures have risen by about $0,65^{\circ} \mathrm{C}$ (Lough, Anderson \& Hughes, 2018), although not uniformly (Fig. 4).

Global warming is well known for its impacts on both terrestrial and marine species. In general, the temperature tolerances of species are related to their biological complexity. Most unicellular organisms in the Archaea, Bacteria, and Eukarya domains have higher temperature tolerances than do multicellular organisms (Fig. 5). Also, the capacity for physiological adaptation is higher for organisms with short generation times (e.g. unicellular organisms) than those with long generation times. Thus most plants and animals are considered more vulnerable to warming than less complex organisms. An interesting example of this rule is with zooxanthellate corals: the adaptation rates of the algal symbionts are fast versus those of the coral host (Császár, Ralph, Frankham, Berkelmans \& van Oppen, 2010), complicating our ability to predict how the entire holobiont will respond.

Mobile marine organisms can avoid ocean warming by shifting their geographic ranges to more favorable temperatures. There is already abundant evidence that fish and other marine species are moving to higher latitudes and to deeper depths (Poloczanska et al., 2013; Feary et al., 2014). Amongst 185 marine species for which distributions have been regularly tracked along the west coast of the United States since the late 1960's, 74\% have moved northward and $70 \%$ have moved into deep water (Pinsky, 2013). These changes are correlated with changes in ocean temperature.

Benthic organisms cannot readily migrate as adults, and the shifts in their ranges reflect generational timescales such as those associated with larval dispersal and settlement in new habitats. During warming events, these species must tolerate the heat stress or die. The most well-known consequence of ocean warming on a benthic species is coral bleaching, the stress-induced expulsion of the symbiotic dinoflagellates (zooxanthellae) that live within the coral tissue. This occurs when water temperatures exceed by $1-2^{\circ} \mathrm{C}$ the normal maximum experienced by corals, over a period of a few weeks. The loss of the dinoflagellates cuts off the supply of carbohydrates produced through their photosynthesis, and can lead to starvation of the coral. Mass coral bleaching events were first documented in the early 1980s. Three global scale mass coral bleaching events have occurred since then, in 1997-1998, 2010, and 2014-2016. The last event affected many coral reefs in Central America (Fig. 6), most of which appeared to recover with rather

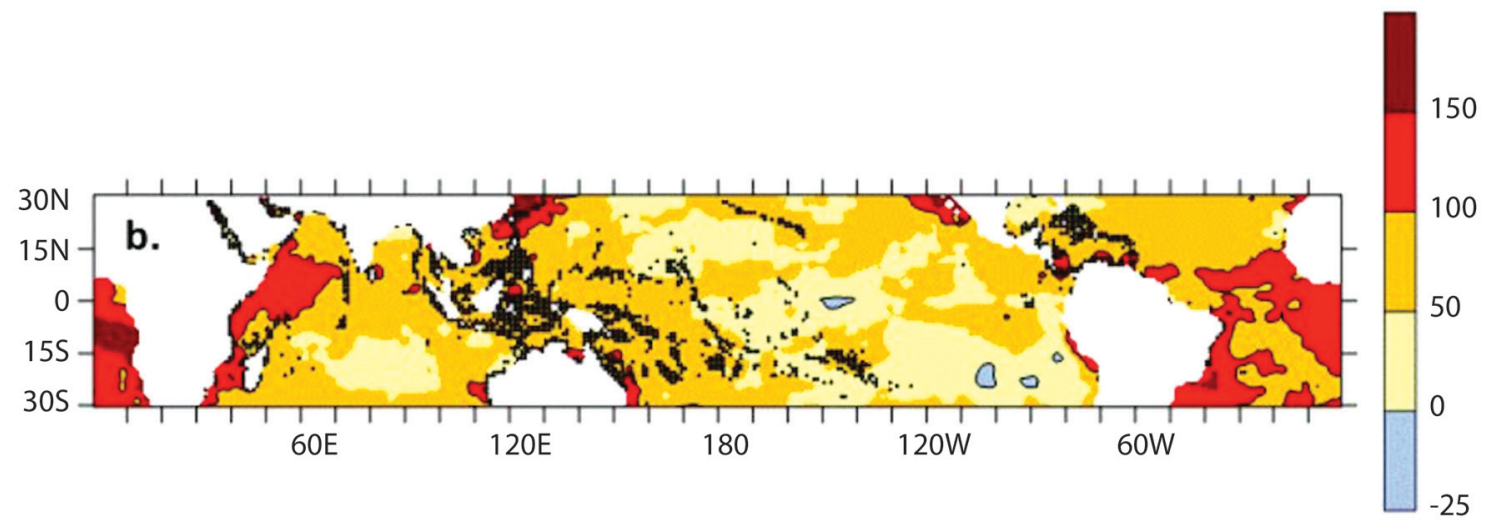

Fig. 4. Average warming of the surface ocean in the tropics over the period 1880-2017, shown as a percentage of the global average temperature. Black symbols show coral reef locations. Figure reprinted from Lough et al. (2018), as licensed under a Creative Commons Attribution 4.0 International license for Scientific Reports. 


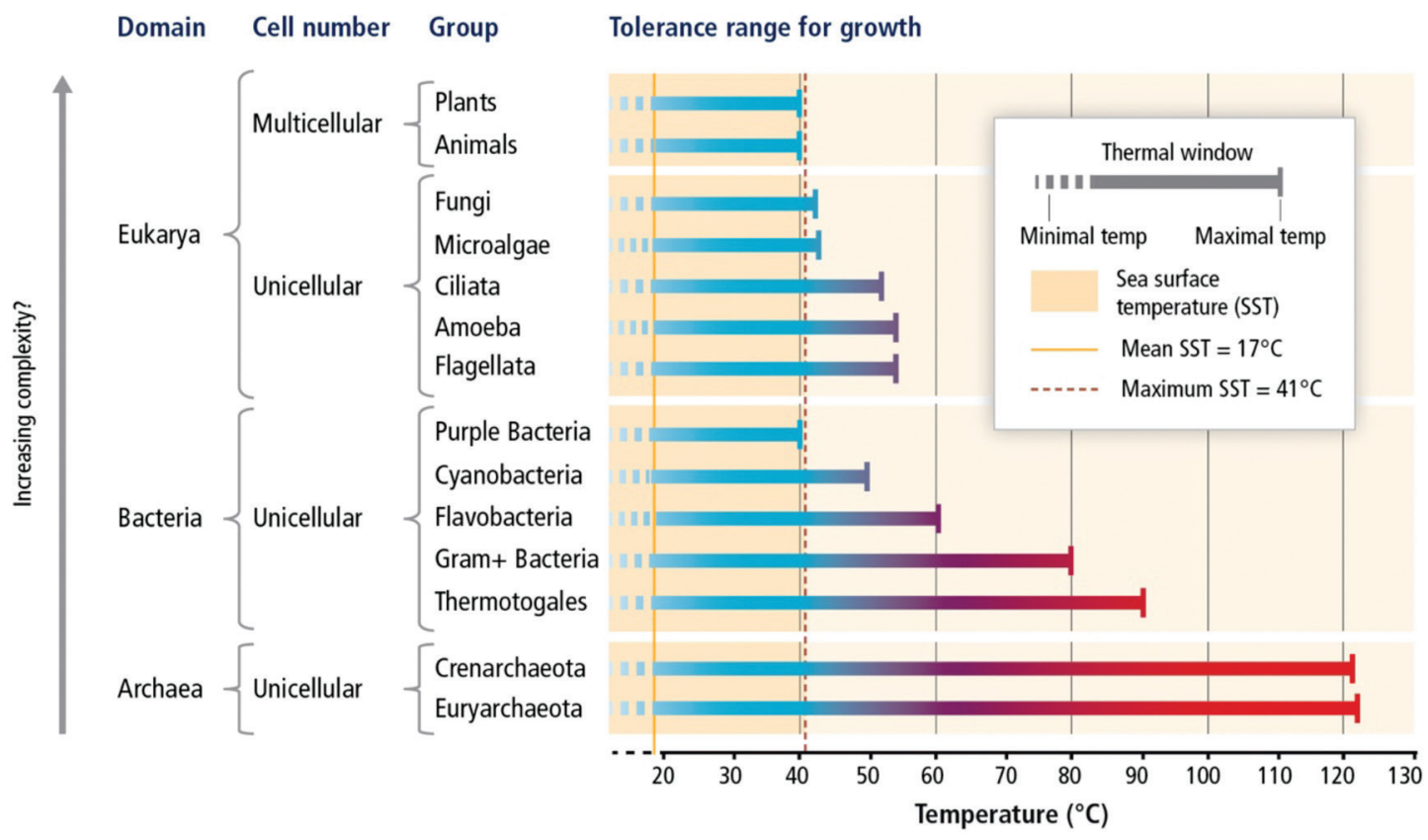

Fig. 5. Comparison of temperature tolerance ranges for growth among the major groups within the Archaea, Bacteria, and Eukarya domains. This is figure 6-6 from (Pörtner et al., 2014), reproduced with permission from the Intergovernmental Panel on Climate Change.

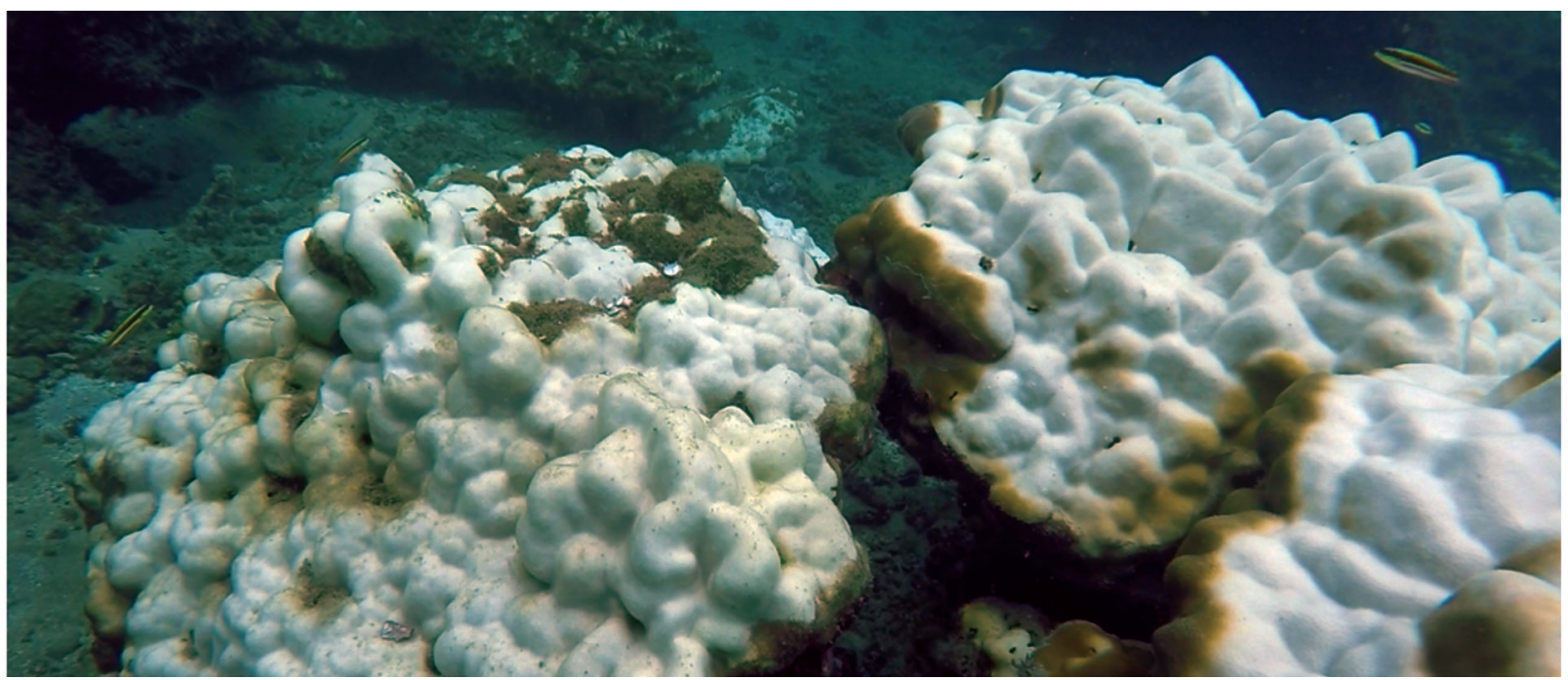

Fig. 6. Bleached colonies of massive Porites sp. in Costa Rica, taken in April, 2016 during the third global bleaching event. The white areas are where the coral has lost the symbiotic algae from its tissues. The darker rims are where the algae are beginning to repopulate the coral tissue.

low rates of mortality. In the northern third of the Great Barrier Reef, however, the event resulted in the mortality of the majority of corals (Hughes et al., 2018). Much of the mortality occurred very rapidly, which is thought to be due to extreme heat stress that killed the corals directly, rather than through starvation following bleaching. With continued warming through this century, coral bleaching events are projected to become too frequent and severe to allow coral reefs to recover sufficiently, so that the coral reef ecosystem in most major reef provinces is likely to collapse across much of its current range, particularly 


\section{A. $100 \mathrm{~m}$}

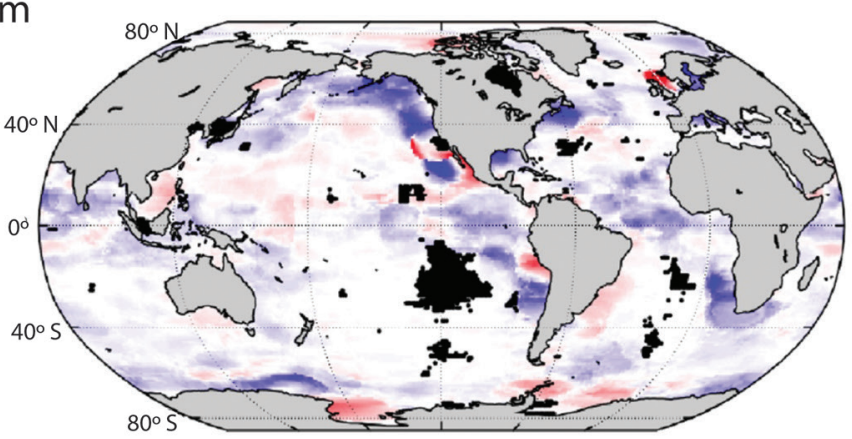

B. $400 \mathrm{~m}$

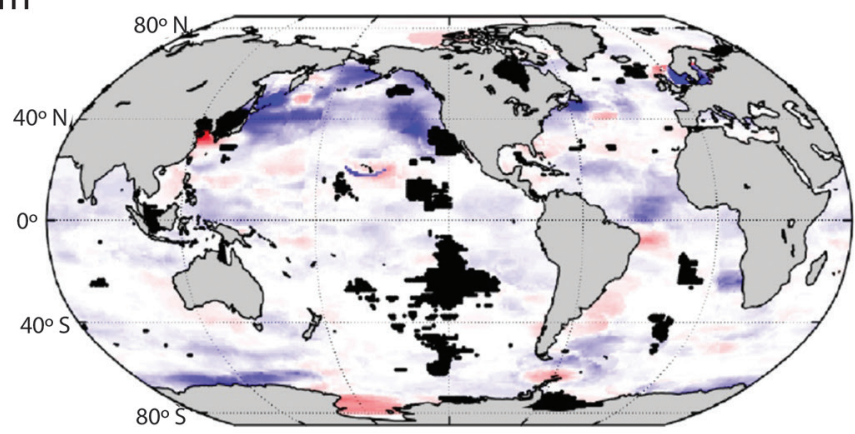

C. $700 \mathrm{~m}$

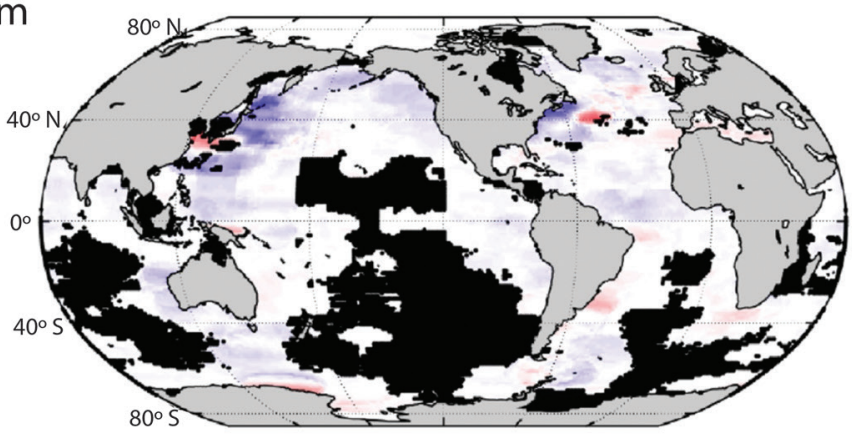

1958 - 201502 trend, $\mu \mathrm{Myr}^{-1}$

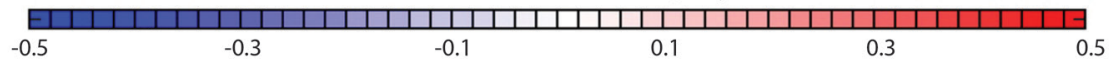

Fig. 7. Trends in dissolved oxygen content (micromoles $\mathrm{O}_{2}$ per year) over the period 1958-2015, calculated for depths of a) $100 \mathrm{~m}$, b) $400 \mathrm{~m}$, and c) $700 \mathrm{~m}$. Trends were not calculated where grid cells had fewer than 20 observations (black regions). Figure from Ito et al. (2017).

where other stressors are not controlled (Wolff, Mumby, Devlin \& Anthony, 2018).

Ocean deoxygenation: Ocean water that is well mixed with the atmosphere is generally saturated with oxygen. But once that water leaves the surface, its oxygen concentration changes naturally in response to physical and biological factors that affect oxygen production at the surface; physical oceanographic processes of ocean through mixing, advection, and diffusion; and processes that consume oxygen such as respiration. Measurements of dissolved oxygen reveal an overall loss of oxygen from the ocean since 1955 (Ito, Minobe, Long \& Deutsch, 2017), but those trends reflect multiple factors that vary widely from region to region (Fig. 7).

Two consequences of ocean warming are leading to a decrease in the concentration of dissolved oxygen in 
the ocean (Gruber, 2011). First, oxygen solubility decreases with increased temperature; that is, as ocean water warms, it absorbs less oxygen from the overlying atmosphere. Second, warming is faster at the surface of the ocean where it is in contact with the atmosphere, leading to increased buoyancy of the surface layer and thus increased stratification; that is, the surface layer become more buoyant and thus more stable, so that it restricts mixing of well-ventilated surface waters with the layers below. These changes lead to a reduction in dissolved oxygen in many regions of the ocean. Although not addressed in this brief summary, stratification also affects the delivery of nutrients to the surface ocean, causing reductions in primary production.

While tracking changes in marine oxygen concentration over time has been difficult, both observations and global coupled ocean circulation models indicate that oxygen concentrations are declining. A recent global analysis of ocean oxygen concentration over its entire depth range indicated a $2 \%$ decrease in oxygen since 1960 (Oschlies, Brandt, Stramma \& Schmidtko, 2018).
About half of the decrease in oxygen concentration in the upper $1000 \mathrm{~m}$ of the ocean can be attributed to the decreased solubility as waters have warmed (Schmidtko, Stramma \& Visbeck, 2017).

The worldwide distribution of oxygen concentration below the mixed layer shows that cooler waters have higher concentrations of oxygen. For Central and South America, oxygen concentration is much lower in the Pacific than in the Atlantic, because Pacific waters are "older" in terms of time since being in contact with the surface, and thus have had more time to lose oxygen via respiration of organic matter.

Oxygen minimum zones (OMZs) occur naturally in midwater regions, particularly where conditions promote high primary production in the surface mixed layer. One such region is known as El Domo Térmico de Costa Rica, or "The Costa Rican Dome" located off the Pacific coast of Costa Rica (Fig. 8) (Jiménez, 2016; Lizano, 2016). Here wind patterns cause a seasonal doming of the thermocline, bringing nutrients from deep water to the surface to stimulate productivity. The high productivity attracts
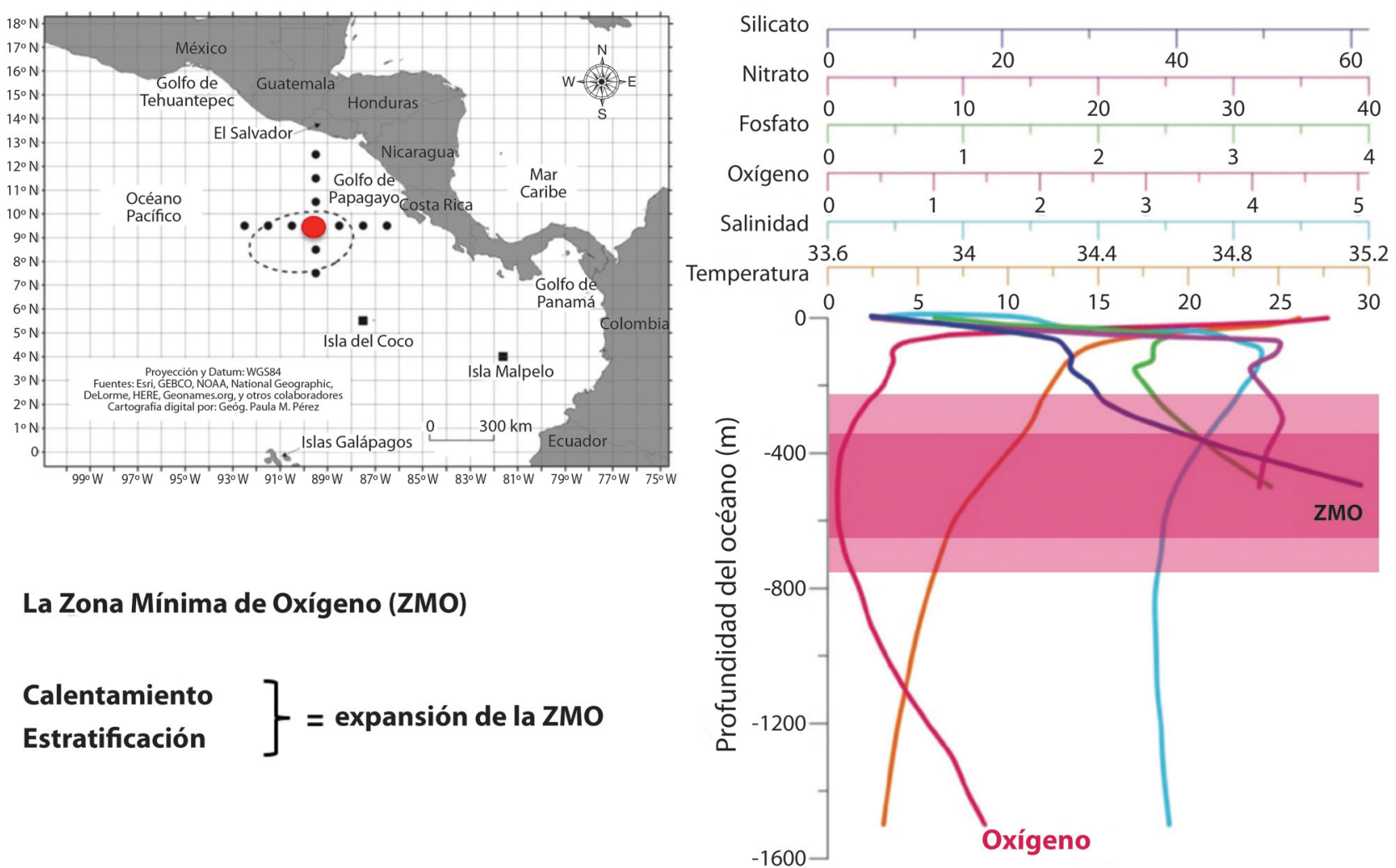

La Zona Mínima de Oxígeno (ZMO)

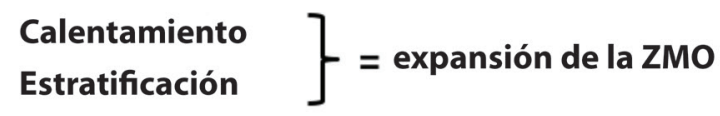


many marine megafauna (Fiedler, 2002). While oxygen is plentiful at the surface, between 400-600 m below the surface almost all of the oxygen is consumed by respiration of the organic matter that sinks from the surface (Fig. 8) (Lizano, 2016). With ocean warming, OMZs such as this one are likely to intensify and expand in thickness, which may interfere with how marine animals utilize this site as a feeding ground (Jiménez, 2016).

\section{Combined impacts of ocean acidification, warm-} ing, and deoxygenation on ocean life: The combined effects of acidification, warming, and deoxygenation of the oceans on any single species is difficult to assess. Species fitness is not only reflected in the physiological tolerance of the stresses, but also in the ability to find mates, reproduce, feed, and interact with its own and other species. These aspects are often poorly studied even with the adult phases of species, much less on other life stages (Dupont, Dorey \& Thorndyke, 2010). The paleontological record, however, documents the changes in marine species and ecosystems during periods of rapid environmental change, and those changes are in line with the expected changes for present day species and ecosystems. The Paleocene-Eocene Thermal Maximum that occurred about 55 million years ago was a period when ocean warming and acidification proceeded very rapidly (Zachos et al., 2005; Dunkley Jones et al., 2013), although still at a rate estimated to be 10 times slower than the rate today (Ridgwell \& Schmidt, 2010). The geographic ranges of many warm-water species shifted poleward, although extinctions and range reductions were common in benthic foraminifera, calcareous algae and corals (Thomas, 2007; Scheibner \& Speijer, 2008).

\section{DISCUSSION}

The recent Fifth Assessment of the Intergovernmental Panel on Climate Change summarized the expected impacts on ocean species and highlighted three main expectations (see summary in Pörtner et al., 2014): (1) shifts in the timing of normal activities of species; (2) shifts in their abundance and geographic distributions, and (3) a reduction in maximum body size. Most of these focus on ocean warming, but it is clear that both acidification and deoxygenation will have further impacts, including the restriction of migration patterns (Deutsch, Ferrel, Seibel, Portner \& Huey, 2015; Kleypas, 2015). Marine ecosystems are not expected to migrate in toto, but rather the differential response of member species will result in their being "pulled apart" which is likely to alter food webs and fisheries.
Can marine ecosystems be managed against this background of environmental change and the uncertain responses of species? Gattuso et al. (2015) outlined four clusters of management that must be implemented to protect marine species in the coming future. The most desirable cluster is mitigation, including (1) protecting the atmosphere and ocean from further increases in atmospheric $\mathrm{CO}_{2}$ and other greenhouse gases that cause acidification, warming and deoxygenation. It also includes reducing other stressors such as pollution, or engineering solutions to tackle at least one of the problems, such as solar radiation management (MacMartin, Ricke \& Keith, 2018). Given the slow progress toward meeting the Paris Agreement (UNFCCC, 2015; Rogelj et al., 2016), however, additional actions will be needed in addition to mitigation, including: (2) protecting marine ecosystems through expansion of marine protected areas, (3) assisting species adaptation and migration by active relocation, and (4) repairing the environment through engineering and repairing ecosystems by restoring them with species and genotypes selected for or bred to withstand the ocean changes.

Without such measures, coral reefs may be the first major marine ecosystem to suffer ecological collapse this century. Active reef restoration is increasingly recognized as a way to speed up reef recovery and, when combined with assisted evolution and assisted migration, as a way to restore reefs with corals that are more resilient to climate change (Rinkevich, 2014). Active restoration has rapidly increased over the past decade within the Caribbean and Mesoamerican reef systems, building on the success in fragment-based propagating and outplanting many thousands of colonies of the threatened species Acropora cervicornis and A. palmata (Young, Schopmeyer \& Lirman, 2012; Schopmeyer et al., 2017), to include many other coral species. Coral restoration efforts on Indo-Pacific reefs have also had marked success (e.g., Montoya-Maya, Smit, Burt \& Frias-Torres, 2016), and have fast-tracked the testing of new methodologies for speeding up growth rates and maximizing survival. Such restoration activities, which are carried out in both in-situ nurseries and land-based aquaculture, provide the platforms for testing and incorporating innovations to accelerate rates of adaptation to rising temperature and acidification, or which reduce the susceptibility to disease. Examples of such innovations include: 1) manipulation of the coral-symbiont combination (Cunning, Silverstein \& Baker, 2015); 2) reproduction-based propagation (Linden \& Rinkevich, 2011), which can also maximize genetic diversity (Van Oppen et al., 2017); 3) microbiome manipulation (Peixoto, Rosado, Leite, Rosado \& Bourne, 2017); and other innovations that result in more resilient corals 
and coral communities. A major challenge with active restoration is the scale at which these activities must be carried out. Strategically building the capacity for reef restoration at many locations and across a variety of reef systems is key to achieving that scale, not only in terms of the hectares of reef that can be restored, but in providing benefits tangible to local communities, which is essential to maintaining long-term commitment to the restoration activities (Kittinger et al., 2016).

E.O. Wilson (1992) prophesized some 25 years ago: "The next century will, I believe, be the era of restoration in ecology." The future of many marine ecosystems depends on our capacity to not only restore them, but to tackle the root causes of climate change, to understand how marine ecosystems will respond to those changes, and, as is increasingly emphasized, to strongly engage society in their restoration (Suding et al., 2015).

\section{ACKNOWLEDGMENTS}

I sincerely thank the organizing committee of the $1^{\text {st }}$ Simposio Sobre Cambio Climático y Biodiversidad, Gustavo Gutiérrez Espeleta, Andrea Vincent Rossi, Carolina Alvarez Vergnani, Laura García Jiménez, Gerardo Jiménez Arce, Lauren Pérez Quesada, for calling attention to climate change in Latin America. Jimena Samper Villareal also deserves a high level of gratitude for her support and persistence in encouraging this manuscript and her continued efforts following the conference. I also wish to thank the University of Costa Rica and particularly my colleagues at Centro de Investigación en Ciencias del Mar y Limnología (CIMAR) for their gracious support during my sabbatical, particularly Jorge Cortés Núñez and Juan José Alvarado. Thanks to Jorge Arturo Jimenez and again to Jorge Cortés Núñez for peer-reviewing this manuscript. University of Costa Rica student Tatiana Villalobos and National University student José Andrés Marín Moraga provided support for the symposium presentation and its translation into Spanish.

\section{REFERENCES}

Alvarez-Filip, L., Gill, J. A., \& Dulvy, N. K. (2011). Complex reef architecture supports more small-bodied fishes and longer food chains on Caribbean reefs. Ecosphere, 2(10), 1-17. DOI:10.1890/es11-00185.1

Császár, N. B. M., Ralph, P. J., Frankham, R., Berkelmans, R., \& van Oppen, M. J. H. (2010). Estimating the potential for adaptation of corals to climate warming. PLoS One, 5(3), e9751. DOI:10.1371/journal.pone.0009751
Cunning, R., Silverstein, R. N., \& Baker, A. C. (2015). Investigating the causes and consequences of symbiont shuffling in a multi-partner reef coral symbiosis under environmental change. Proceedings of the Royal Society B-Biological Sciences, 282(1809), 20141725. DOI:10.1098/ rspb.2014.1725

Deutsch, C., Ferrel, A., Seibel, B., Portner, H. O., \& Huey, R. B. (2015). Climate change tightens a metabolic constraint on marine habitats. Science, 348(6239), 1132-1135. DOI:10.1126/science.aaa1605

Doropoulos, C., Ward, S., Marshell, A., Diaz-Pulido, G., \& Mumby, P. J. (2012). Interactions among chronic and acute impacts on coral recruits: the importance of size-escape thresholds. Ecology, 93(10), 2131-2138

Dunkley Jones, T., Lunt, D. J., Schmidt, D. N., Ridgwell, A., Sluijs, A., Valdes, P. J., \& Maslin, M. (2013). Climate model and proxy data constraints on ocean warming across the Paleocene-Eocene Thermal Maximum. Earth-Science Reviews, 125, 123-145. DOI:10.1016/j. earscirev.2013.07.004

Dupont, S., Dorey, N., \& Thorndyke, M. (2010). What meta-analysis can tell us about vulnerability of marine biodiversity to ocean acidification? Estuarine, Coastal and Shelf Science, 89(2), 182-185. DOI:10.1016/j.ecss.2010.06.013

Fabricius, K. E., Langdon, C., Uthicke, S., Humphrey, C., Noonan, S., De'ath, G., ... Lough, J. M. (2011). Losers and winners in coral reefs acclimatized to elevated carbon dioxide concentrations. Nature Climate Change, 1(3), 165-169. DOI:10.1038/nclimate 1122

Fabricius, K. E., Noonan, S. H. C., Abrego, D., Harrington, L., \& De'ath, G. (2017). Low recruitment due to altered settlement substrata as primary constraint for coral communities under ocean acidification. Proceedings of the Royal Society B-Biological Sciences, 284(1862), 20171536. DOI:10.1098/rspb.2017.1536

Feary, D. A., Pratchett, M. S., Emslie, M. J., Fowler, A. M., Figueira, W. F., Luiz, O. J., ... Booth, D. J. (2014). Latitudinal shifts in coral reef fishes: why some species do and others do not shift. Fish and Fisheries, 15(4), 593-615. DOI:10.1111/ faf.12036

Fiedler, P. C. (2002). Environmental change in the Eastern Tropical Pacific Ocean: review of ENSO and decadal variability. Marine Ecology Progress Series, 244, 265-283.

Gattuso, J. P., Magnan, A., Bille, R., Cheung, W. W. L., Howes, E. L., Joos, F., ... Turley, C. (2015). Contrasting futures for ocean and society from different anthropogenic $\mathrm{CO}_{2}$ emissions scenarios. Science, 349(6243). DOI:10.1126/ science.aac 4722

Gruber, N. (2011). Warming up, turning sour, losing breath: ocean biogeochemistry under global change. Philosophical Transactions of the Royal Society a-Mathematical Physical and Engineering Sciences, 369(1943), 1980-1996. DOI:10.1098/rsta.2011.0003

Hall-Spencer, J. M., Rodolfo-Metalpa, R., Martin, S., Ransome, E., Fine, M., Turner, S. M., ... Buia, M. C. (2008). Volcanic 
carbon dioxide vents show ecosystem effects of ocean acidification. Nature, 454(7200), 96-99. DOI:10.1038/ nature07051

Hughes, T. P., Kerry, J. T., Baird, A. H., Connolly, S. R., Dietzel, A., Eakin, C. M., ... Torda, G. (2018). Global warming transforms coral reef assemblages. Nature, 556(7702), 492-+. DOI:10.1038/s41586-018-0041-2

Inoue, S., Kayanne, H., Yamamoto, S., \& Kurihara, H. (2013). Spatial community shift from hard to soft corals in acidified water. Nature Climate Change, 3(7), 683-687. DOI:10.1038/nclimate1855

Ito, T., Minobe, S., Long, M. C., \& Deutsch, C. (2017). Upper ocean O trends: 1958-2015. Geophysical Research Letters, 44, 4214-4223. DOI:10.1002/2017GL073613.

Jiménez, J. A. (2016). El Domo Térmico de Costa Rica: Un oasis de productividad frente a las costas del Pacífico Centroaméricano. San José, Costa Rica: Fundación MarViva Ed.

Khatiwala, S., Tanhua, T., Fletcher, S. M., Gerber, M., Doney, S. C., Graven, H. D., ... Sabine, C. L. (2013). Global ocean storage of anthropogenic carbon. Biogeosciences, 10(4), 2169-2191. DOI:10.5194/bg-10-2169-2013

Kittinger, J. N., Bambico, T. M., Minton, D., Miller, A., Mejia, M., Kalei, N., ... Glazier, E. W. (2016). Restoring ecosystems, restoring community: socioeconomic and cultural dimensions of a community-based coral reef restoration project. Regional Environmental Change, 16(2), 301-313. DOI:10.1007/s10113-013-0572-x

Kleypas, J. (2015). Invisible barriers to dispersal. Science, 348(6239), 1086-1087. DOI:10.1126/science.aab4122

Kleypas, J. A. (in press). The impacts of ocean acidification on marine biodiversity. In T. E. Lovejoy \& L. Hannah (Eds.), Climate Change and Biodiversity. USA: Yale University Press.

Le Quéré, C., Andrew, R. M., Friedlingstein, P., Sitch, S., Pongratz, J., Manning, A. C., ... Zhu, D. (2018). Global Carbon Budget 2017. Earth System Science Data, 10(1), 405-448. DOI:10.5194/essd-10-405-2018

Linden, B., \& Rinkevich, B. (2011). Creating stocks of young colonies from brooding coral larvae, amenable to active reef restoration. Journal of Experimental Marine Biology and Ecology, 398(1-2), 40-46. DOI:10.1016/j. jembe.2010.12.002

Lizano, O. G. (2016). Distribución espacio-temporal de la temperatura, salinidad y oxígeno disuelto alrededor del Domo Térmico de Costa Rica. Revista de Biologia Tropical, 64, S135-S152.

Lough, J. M., Anderson, K. D., \& Hughes, T. P. (2018). Increasing thermal stress for tropical coral reefs: $1871-2017$.Scientific Reports, 8, 6079. DOI:10.1038/s41598-018-24530-9

MacMartin, D. G., Ricke, K. L., \& Keith, D. W. (2018). Solar geoengineering as part of an overall strategy for meeting the 1.5 degrees C Paris target. Philosophical Transactions of the Royal Society A-Mathematical Physical and Engineering Sciences, 376(2119), 20160454. DOI:10.1098/ rsta.2016.0454

Montoya-Maya, P. H., Smit, K. P., Burt, A. J., \& Frias-Torres, S. (2016). Large-scale coral reef restoration could assist natural recovery in Seychelles, Indian Ocean. Nature Conservation-Bulgaria(16), 1-17. DOI:10.3897/ natureconservation.16.8604

Mora, C., Tittensor, D. P., Adl, S., Simpson, A. G. B., \& Worm, B. (2011). How many species are there on Earth and in the ocean? PLoS Biology, 9(8), e1001127. DOI:10.1371/journal.pbio. 1001127

NOAA (National Centers for Environmental Information). (2018). Climate at a glance: Global time series. Retrieved from https://www.ncdc.noaa.gov/cag/

Oschlies, A., Brandt, P., Stramma, L., \& Schmidtko, S. (2018). Drivers and mechanisms of ocean deoxygenation. Nature Geoscience, 11, 467-473. DOI:10.1038/ s41561-018-0152-2

Peixoto, R. S., Rosado, P. M., Leite, D. C. d. A., Rosado, A. S., \& Bourne, D. G. (2017). Beneficial microorganisms for corals (BMC): proposed mechanisms for coral health and resilience. Frontiers in Microbiology, 8, 341. DOI:10.3389/ fmicb.2017.00341

Pinsky, M. L. (2013). Effects of climate velocity on fish and fisheries. Paper presented at the Speaker Paper for Managing Our Nation's Fisheries; Session 2: Advancing EcosystemBased Decision Making, Washington, DC.

Poloczanska, E. S., Brown, C. J., Sydeman, W. J., Kiessling, W., Schoeman, D. S., Moore, P. J., ... Richardson, A. J. (2013). Global imprint of climate change on marine life. Nature Climate Change, 3(10), 919-925. DOI:10.1038/ nclimate1958

Pörtner, H.-O., Karl, D. M., Boyd, P. W., Cheung, W. W. L., LluchCota, S. E., Nojiri, Y., . . . Zavialov, P. O. (2014). Ocean systems. In C. B. Field, V. Barros, D. Dokken, K. Mach, M. Mastrandrea, T. Bilir, M. Chatterjee, K. Ebi, Y. Estrada, R. Genova, B. Girma, E. Kissel, A. Levy, S. MacCracken, P. Mastrandrea, \& L. White (Eds.), Climate Change 2014: Impacts, Adaptation, and Vulnerability. Part A: Global and Sectoral Aspects. Contribution of Working Group II to the Fifth Assessment Report of the Intergovernmental Panel on Climate Change (pp. 411-484). Cambridge, United Kingdom and New York, NY, USA: Cambridge University Press.

Ridgwell, A., \& Schmidt, D. N. (2010). Past constraints on the vulnerability of marine calcifiers to massive carbon dioxide release. Nature Geoscience, 3(3), 196-200. DOI:10.1038/ ngeo755

Rinkevich, B. (2014). Rebuilding coral reefs: does active reef restoration lead to sustainable reefs? Current Opinion in Environmental Sustainability, 7, 28-36. DOI:10.1016/j. cosust.2013.11.018

Rogelj, J., den Elzen, M., Hohne, N., Fransen, T., Fekete, H., Winkler, H., ... Meinshausen, M. (2016). Paris Agreement climate 
proposals need a boost to keep warming well below 2 degrees C. Nature, 534(7609), 631-639. DOI:10.1038/ nature18307

Sabine, C. L., Feely, R. A., Gruber, N., Key, R. M., Lee, K., Bullister, J. L., ... Rios, A. F. (2004). The oceanic sink for anthropogenic $\mathrm{CO}_{2}$. Science, 305(5682), 367-371.

Scheibner, C., \& Speijer, R. P. (2008). Late Paleocene-early Eocene Tethyan carbonate platform evolution - A response to long- and short-term paleoclimatic change. Earth-Science Reviews, 90(3-4), 71-102. DOI:10.1016/j. earscirev.2008.07.002

Schmidtko, S., Stramma, L., \& Visbeck, M. (2017). Decline in global oceanic oxygen content during the past five decades. Nature, 542(7641), 335. DOI:10.1038/nature21399

Schopmeyer, S. A., Lirman, D., Bartels, E., Gilliam, D. S., Goergen, E. A., Griffin, S. P., ... Walter, C. S. (2017). Regional restoration benchmarks for Acropora cervicornis. Coral Reefs, 36(4), 1047-1057. DOI:10.1007/s00338-017-1596-3

Suding, K., Higgs, E., Palmer, M., Callicott, J. B., Anderson, C. B., Baker, M., ... Schwartz, K. Z. S. (2015). Committing to ecological restoration. Science, 348(6235), 638-640. DOI:10.1126/science.aaa4216

Thomas, E. (2007). Cenozoic mass extinctions in the deep sea: what perturbs the largest habitat on earth? In S. Monechi, R. Coccioni, \& M. R. Rampino (Eds.), Large Scale Ecosystem Perturbation: Causes and Consequences, Geological Society of America Special Paper 424 ( $p$ p. 1-23). Boulder, CO, USA: Geological Society of America.
UNFCCC. (2015). Adoption of the Paris Agreement, Report No. FCCC/CP/2015/L.9/Rev.1. Retrieved from http://unfccc.int/resource/docs/2015/cop21/eng/l09r01.pdf (UNFCCC, 2015):

Van Oppen, M. J. H., Gates, R. D., Blackall, L. L., Cantin, N., Chakravarti, L. J., Chan, W. Y., ... Putnam, H. M. (2017). Shifting paradigms in restoration of the world's coral reefs. Global Change Biology, 23(9), 3437-3448. DOI:10.1111/gcb.13647

Webster, N. S., Uthicke, S., Botte, E. S., Flores, F., \& Negri, A. P. (2013). Ocean acidification reduces induction of coral settlement by crustose coralline algae. Global Change Biology, 19(1), 303-315. DOI:10.1111/gcb.12008

Wilson, E. O. (1992). The Diversity of Life. Cambridge, MA: Harvard University Press.

Wolff, N. H., Mumby, P. J., Devlin, M., \& Anthony, K. R. N. (2018). Vulnerability of the Great Barrier Reef to climate change and local pressures. Global Change Biology, 24(5), 19781991. DOI:10.1111/gcb.14043

Young, C. N., Schopmeyer, S. A., \& Lirman, D. (2012). A review of reef restoration and coral propagation using the threatened genus Acropora in the Caribbean and western Atlantic. Bulletin of Marine Science, 88(4), 1075-1098. DOI:10.5343/bms.2011.1143

Zachos, J. C., Rohl, U., Schellenberg, S. A., Sluijs, A., Hodell, D. A., Kelly, D. C., ... Kroon, D. (2005). Rapid acidification of the ocean during the Paleocene-Eocene thermal maximum. Science, 308(5728), 1611-1615. 